\title{
DIURETICS EFFECT OF AVOCADO LEAF (PERSEA AMERICANA MILL.) ETHANOL EXTRACT ON THE GASTRIC HISTOLOGY OF WISTAR MALE RATS (RATTUS NORVEGICUS)
}

\author{
Dwi Erlinda, Mahriani, \& Susantin Fajariyah* \\ Majors Biology, FMIPA, Universitas Jember (UNEJ), Indonesia \\ Submited : 24-10-2019; Accepted : 11-03-2020: Published : 10-08-2020 \\ *Corresponding author: E-mail : susantin.fmipa@unej.ac.id
}

\begin{abstract}
Irregular urine output triggers kidney stone disease. One way to cure it is by using synthetic diuretic compounds. The use of synthetic diuretic drugs for a long time can cause side effects, namely gastric damage. Therefore, research is needed to determine the diuretic effect of ethanol extract of avocado leaves (Persea americana) and its effect on the histological structure of the gastric of male rats. Avocado leaf extract is made by maceration method, using $70 \%$ ethanol and then evaporated. Wistar male rats were divided into 5 treatment groups namely negative control (aquadest), positive control (furosemide), avocado leaf extract dose of $50 \mathrm{mg} / \mathrm{kg}$ body weight, $100 \mathrm{mg} / \mathrm{kg}$ body weight, and $150 \mathrm{mg} / \mathrm{kg}$ body weight with oral administration for 15 days. The volume of urine was measured for 24 hours, then the mice were sacrified on the 16th day. Gastric organs were taken for histological observation by the paraffin method and Hematoxylin and Eosin (H\&E) staining. The results showed that the optimum avocado leaf ethanol extract was a dose of $100 \mathrm{mg} / \mathrm{kg}$ showed a diuretic effect but did not affect the histological structure of the gastric.
\end{abstract}

Keywords: diuretics, ethanol extract of leaves of avocado, gastric histological structure

How to Cite: Erlinda, D., Mahriani, \& Fajariyah, S. (2020). Diuretics Effect Of Avocado Leaf (Persea americana Mill.) Ethanol Extract on The Gastric Histology of Wistar Male Rats (Rattus norvegicus), BioLink: Jurnal Biologi Lingkungan, Industri dan Kesehatan, Vol.7 (1): Hal. 62-70 


\section{INTRODUCTION}

Smoothless urinary output triggers the onset of kidney stone disease. Increasment the rate of urine output is one way to cure kidney stone disease. Diuretic drugs use to increase water expenditure with unabsorbed solutes such as sodium ions and chlorides (Guyton \& Hall, 2014).

Currently there are many synthetic diuretics that have been used to increase the rate of urine output, including furosemide. The use of synthetic diuretics in a long period cause side effects such as impaired kidney function and stomach damage (Siswandono and Soekardjo, 2008).

Stomach is a digestive organ that functions to store food, secrete $\mathrm{HCl}$ and enzymes for protein digestion. Anatomically the stomach is divided into four parts respectively cardia, fundus, corpus, and pylorus (Mescher, 2017).

Disturbances in the stomach are caused by an imbalance between the gastric juice secretion and protection by the gastroduodenal mucosa and neutralization of gastric acid by duodenal gum (Sherwood, 2012). Phylorus is the part of the stomach that is often disturbed (Puspitasari, 2008).

Instead of using synthetic diuretic, it can be used natural ingredients, namely avocado leaf extract (Persea americana Mill) to avoid disruptive effects.

Avocados are traditional medicines that have the ability to treat diseases such as mouth sores, bladder stones, toothaches, dry faces, swelling due to inflammation and also diabetes (Katja et al, 2009). Avocado leaves contain chemical compounds including flavonoids, saponins, tannins and steroids (Rahman et al, 2018).

Flavonoids are potent antioxidants that can bind free radicals. Flavonoid antioxidant activity is more effective than vitamins C, E and carotenoids (Dai and Mumper, 2010). Tannins function to accelerate wound healing and inflammation of the mucous membrane (Arukwe et al., 2012)

Avocado leaves are reported to be effective, among others, as analgesic drugs, hypertension, hypoglycemia, diarrhea, hemorrhage, anti-inflammation and diuretics (Kurniawan, 2014). According to Adha (2009), treatment of avocado leaf extract containing flavonoids at a dose of $100 \mathrm{mg} / \mathrm{kg}$ bb in SpragueDawley male white rats produce higher total urine yields than furosemide which is usually used as a diuretic drug.

Long term effect using syntetic diuretic cause interference the gastric structure. Therefore, it is necessary to conduct research that aims to determine 
the diuretic effect of ethanol extract of avocado leaves as a natural diuretic on the histological structure of the stomach.

\section{MATERIALS AND METHODS}

The study was conducted at the Zoology Laboratory and the Botany Laboratory of the Department of Biology FMIPA, University of Jember. The study was conducted using a Completely Randomized Design (CRD), with the implementation stages, namely:

\section{Preparation of Avocado Leaves Ethanol Extract}

Dark green avocado leaves are obtained from the Tegalboto Kidul Jember area, then cleaned and separated with leaf bones. The leaves are roasted at $40^{\circ} \mathrm{C}$ for 4 days to dry, then ground and sieved (60 mesh) to produce powder. Avocado leaf extract is made by maceration method, using $70 \%$ ethanol with a ratio of $1: 10$, for 2x24 hours. Avocado leaf maceration results are evaporated with a rotary evaporator at a temperature of $70^{\circ} \mathrm{C}$ and a speed of $50 \mathrm{rpm}$, so that the avocado leaf extract is produced.

\section{Fitochemical assay of Avocado Leaves}

A. Flavanoid Test

As much as 0.1 gram of avocado leaf extract mix with methanol until submerged and then heated. The filtrate was added with concentrated $\mathrm{H} 2 \mathrm{SO}$ 4. The formation of red colour indicates flavonoids.

A. B. Tanin Test

A total of 0.1 grams of ethanol extract of avocado leaves mix with $5 \mathrm{ml}$ of distilled water then heated to boiling for 5 minutes and filtered. After that, the filtrate was added with 5 drops of $\mathrm{FeCl} 3$ 1\% (w / $v)$. The presence of tannin is indicated by the formation of dark blue or greenish black colour .

\section{Animal and Treatment}

The animals used in the study were male rats (Rattus norvegicus) Wistar strain aged 2 months and body weight 200g. Rats were obtained from PUSVETMA Surabaya and adapted in a metabolic cage for 7 days, and given feed in the form of pellets and drinking aquadest on an ad libitum basis. Rats were divided into 5 treatment groups respectively negative control (distilled water), positive control (5.04 mg / kg body weight furosemide), ethanol extract of avocado leaves at a dose of $50 \mathrm{mg} / \mathrm{kg}$ body weight, $100 \mathrm{mg}$ / kg body weight and $150 \mathrm{mg} / \mathrm{kg}$ body weight.

The treatment of test animals in this study using the Lipschitz method, before the treatment of rats fasted for \pm 18 hours. 
After that the rats were given a loading dose of $1 \mathrm{ml}$ of warm aquadest and left for 30 minutes. Furthermore, rats were treated orally according to the dosage using gastric sonde for 15 days (Wientarsih et al, 2012).

On the first day after the last treatment, the rats were not given food and drink, then a diuretic test was performed and the total urine volume was measured for 24 hours. Mice were killed on day 16 by being anesthetized using 0.1 $\mathrm{ml}$ of Ketamine and $0.02 \mathrm{ml}$ of Xyla per mouse, then dissected. Furthermore, the gastric organs are taken part of the pylorus to make histological preparations with the paraffin block method and Hematoxylin and Eosin staining.

\section{Urine Volume Measurement}

Rats were placed in a metabolic cage equipped with a urine container, the urine obtained was measured with a measuring cup. Measurement of total urine volume for 24 hours after the last treatment.

\section{Preparations of Gastric Histology}

Gastric organs is carried out for the preparation of gastric histology preparations of the pylorus. The method

used is the paraffin method and the staining of HE (Haemotoxylin-Eosin). Paraffin methods include fixation, dehydration, clearing, infiltration, embedding, sectioning, affixing, staining, and mounting.

\section{Observing Gastric Histology}

\section{A. Measurement of Gastric Mucosa} Thickness

Measurement of the thickness of the gastric mucosa was carried out using a 400x magnification microscope.

\section{B. Calculation of the Number of Parietal} Cells

Calculation of the number of parietal cells is carried out qualitatively in the epithelial section. The number of parietal cells is counted in 10 fields of view (Puspitasari, 2008). The results of the calculation of the number of parietal cells are divided into 3 groups, namely:

(+) : Number of parietal cells 20-39

$(++) \quad$ : Number of parietal cells 40-59

$(+++):$ Number of parietal cells $\geq 60$

\section{Data Analysis}

Data on urine volume and thickness of the gastric mucosa obtained from the results of the study were analyzed using the One Way ANOVA test with a confidence level of $99 \%$ or $\alpha=0.01$ followed by the Duncan Multiple Range Test (DMRT) to see significant differences between dose treatment groups. 


\section{RESULTS AND DISCUSSION}

Chemical content analysis of the ethanol extract of avocado leaves in this study using a qualitative phytochemical screening test to detect the presence of flavonoids and tannins. The results of the chemical assay or the ethanol extract of avocado leaves can be seen in Table 1 .

Table 1. Qualitatively chemical compounds in the ethanol extract of avocado leaves.

\begin{tabular}{cl} 
Secondary metabolites & Results \\
\hline Flavonoid & Positive \\
\hline Tanin & Positive \\
\hline
\end{tabular}

Based on Table 1, avocado leaf extract contains flavonoids (positive) which are marked by the formation of red color, and contains tannins (positive) characterized by the formation of greenish black color. This is similar with the research of Adha (2009) that avocado leaves contain flavonoid compounds and tannins. Flavonoids are potent antioxidants, and are diuretic (Nessa et al, 2013) while tannins serve to accelerate wound healing and inflammation of the mucous membrane (Arukwe et al., 2012).

\section{Avocado Leaves Extract Diuretic Activity Test}

Diuretic test is done by measuring the total urine volume of male white rats (Rattus norvegicus) for 24 hours. The observation of total urine volume for 24 hours can be seen in Table 2 .

Table 2. Total urine volume of white rats after administration of ethanol extract for avocado leaves during 24 hours

\begin{tabular}{cc}
\hline Dose & Urine Volume (ml) \\
\cline { 2 - 2 } Treatment & $(\mathrm{X} \pm \mathrm{SD})$ \\
\hline Negative Control & $1,87 \pm 1,04^{\mathrm{a}}$ \\
Positive Control & $1,96 \pm 0,92^{\mathrm{a}}$ \\
$50 \mathrm{mg} / \mathrm{kg} \mathrm{bb}$ & $2,53 \pm 1,60^{\mathrm{ab}}$ \\
$100 \mathrm{mg} / \mathrm{kg} \mathrm{bb}$ & $2,54 \pm 1,17^{\mathrm{ab}}$ \\
$150 \mathrm{mg} / \mathrm{kg} \mathrm{bb}$ & $3,32 \pm 1,61^{\mathrm{b}}$ \\
\hline
\end{tabular}

Note: numbers followed by the same letters in the same column show no significant difference in the DMRT test with a significance level $\alpha$ $=0.01$.

Based on the Anova test, the avocado leaf ethanol extract treatment had a very significant effect on the increase in the total urine volume of white rats compared to the negative and positive controls. Duncan test results of 24-hour total urine volume showed that the treatment group of $150 \mathrm{mg} / \mathrm{kg}$ bw ethanol extract of avocado leaves was significantly different from the negative control group and the positive control group. The total urine volume of $150 \mathrm{mg} / \mathrm{kg}$ bw (3.32 ml ) was highest compared to the other groups. Chemical compounds that are thought to have a diuretic effect on ethanol extract of avocado leaves are flavonoids.

Flavonoids increase urine volume expenditure and increase excretion of Sodium, Potassium and Chlorid in urine (Omodamiro \& Jimoh, 2016). This is consistent with the results of the study of Adha (2009) administration of ethanol extract of avocado leaves containing 
flavonoids at a dose of $100 \mathrm{mg} / \mathrm{kg}$ bw resulting in more urine volume compared to the control group urine volume and administration of furosemide in SpragueDawley male rats.

The control group's urine volume was negative for 24 hours at the lowest compared to the other treatment groups, this shows that the treatment of furosemide and ethanol extract of avocado leaves can increase urine volume.

\section{Histological Structure of Rat Stomach After Giving Avocado Leaf Ethanol Extract}

Histological structure of the rat's stomach after the ethanol extract of avocado leaves was observed by measuring the thickness of the gastric mucosa and counting the number of parietal cells. Pylorus is more sensitive to acids than other parts of the stomach (Puspitasari, 2008).

The results of the tunica mucosa thickness can be seen in Table 3. Anova test shows that the treatment of avocado leaf extract has a very significant effect on the thickness of tunica mucosa. Further tests with Duncan, avocado leaf extract dose of $150 \mathrm{mg} / \mathrm{kg}$ bw were very significantly different from the negative control group, positive control and the treatment group were doses of $50 \mathrm{mg} / \mathrm{kg}$ bw and doses of $100 \mathrm{mg} / \mathrm{kg} \mathrm{bw}$.
Table 3. Average tunica mucosa thickness of gastric male white rat (Rattus norvegicus) after administration of ethanol extract of avocado leaves

\begin{tabular}{cc}
\hline \multirow{2}{*}{ Treatment } & $\begin{array}{c}\text { Thickness of Tunica Mukosa } \\
(\boldsymbol{\mu} \mathbf{m})\end{array}$ \\
\cline { 2 - 2 } & ${\mathbf{1 5 ~ D a y s ~}\left(^{\left.\overline{\boldsymbol{x}}_{ \pm} \mathrm{SD}\right)}\right.}^{296,09 \pm 74,00^{\mathrm{a}}}$ \\
\hline Negative Control & $288,04 \pm 16,39^{\mathrm{a}}$ \\
Positive Control & $297,65 \pm 50,37^{\mathrm{a}}$ \\
$50 \mathrm{mg} / \mathrm{kg} \mathrm{bb}$ & $311,68 \pm 17,35^{\mathrm{a}}$ \\
$100 \mathrm{mg} / \mathrm{kg} \mathrm{bb}$ & $387,70 \pm 14,62^{\mathrm{b}}$ \\
\hline $150 \mathrm{mg} / \mathrm{kg} \mathrm{bb}$ & \\
\hline
\end{tabular}

Note: numbers followed by the same letter in the same column show no significant difference in the DMRT test with a significance level $\alpha=0.01$

The treatment of avocado leaves ethanol extract tends to increase the thickness of the tunica mucosa at a dose of $50 \mathrm{mg} / \mathrm{kg}$ and $100 \mathrm{mg} / \mathrm{kg}$. This is presumably because the ethanol extract of avocado leaves functions to maintain the the mucous membrane integrity. Tannins have an astringent effect that causes precipitation of micro-proteins on the outer surface of epithelial cells in the stomach to form a protective layer that prevents absorption of toxic substances and maintains the gastric mucosal layer against the action of proteolytic enzymes (Salawu et al., 2009 ). Flavonoids act as antioxidants, compounds that can capture free radicals that can cause damage to the gastric mucosa (Bintari et al., 2014). The thickness of the gastric mucosa after treatment of avocado leaf extract (Persea americana) can be observed in the following gastric structure (Picture 1). 

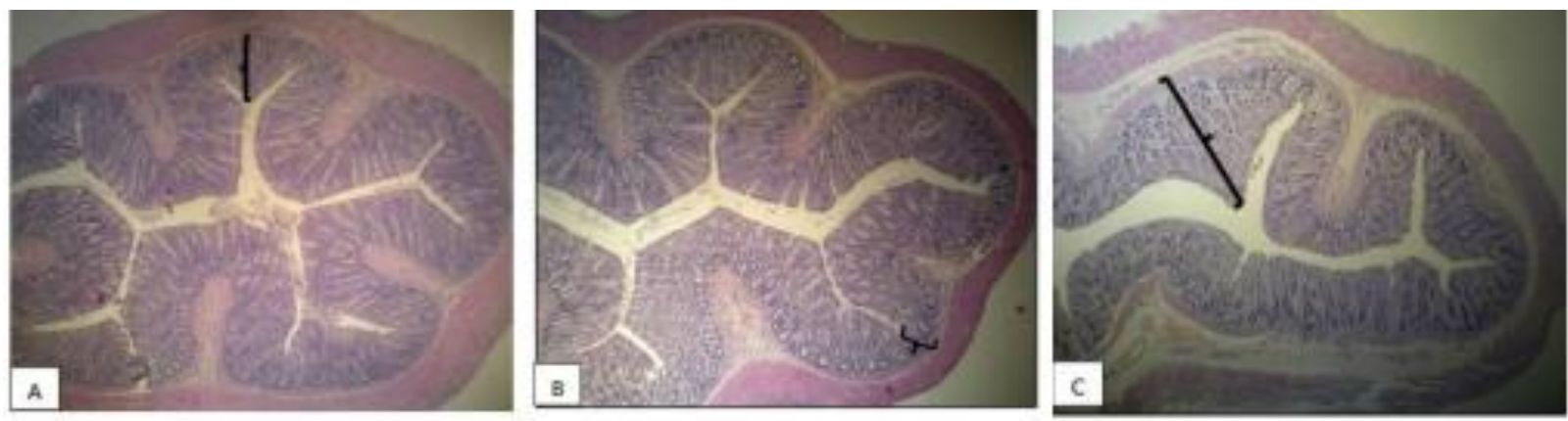

Picture 1. Tunica mucosa thickness after avocado leaf extract (Persea americana) (400x magnification) A. Negative control, B. Positive control, C. dose of $150 \mathrm{mg} / \mathrm{kg}$

The use of synthetic diuretic drugs causes damage to the stomach. In this study the use of avocado leaf extract did not damage the stomach because of the presence of tannins and flavonoids which function as protectors for the gastric mucosa. The optimum treatment of avocado leaf extract is up to a dose of 100 mg / kgbw, because a dose of 150mg / kgbw shows the thickness of the tunica mucosa significantly increased compared to the control, but the structure is normal. The mechanism of thickened gastric epithelium is unknown.

Based on Table 4, it can be seen that the number of parietal cells in the stomach tends to increase with increasing treatment dose.

Table 4. Qualitatively the number of parietal cells in mucosa of the gastric male white rat (Rattus norvegicus) after administration of ethanol extract of avocado leaves

\begin{tabular}{ccc}
\hline Treatment & $\begin{array}{c}\text { Number of } \\
\text { Parietal Cells }\end{array}$ & Scoring \\
\hline control (-) & 44 & ++ \\
control(+) & 37 & + \\
$50 \mathrm{mg} / \mathrm{kg} \mathrm{bb}$ & 49 & ++ \\
$100 \mathrm{mg} / \mathrm{kg} \mathrm{bb}$ & 54 & ++ \\
\hline
\end{tabular}

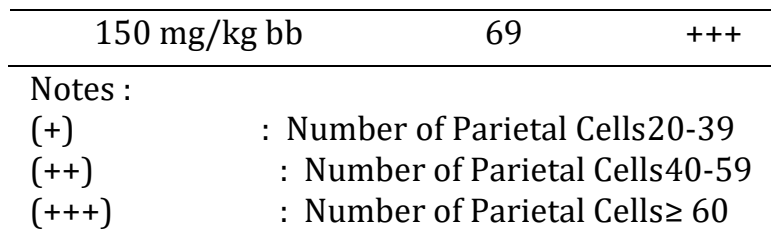

Positive control had the lowest parietal cells number compared to other treatment groups, this showed that furosemide treatment tended to reduce the number of parietal cells, while the treatment of avocado leaf extract could increase the number of parietal cells. This is presumably due to the flavonoid content in the ethanol extract of avocado leaves.

Flavonoids in addition to playing a role in diuretics and anti-inflammatory, also acts as an antioxidant. Antioxidants can capture free radicals (Omodamiro \& Jimoh, 2016). Free radicals are molecules that cause lipid peroxide in the gastric mucosa, so cell membrane permeability increases. Increased permeability will facilitate the diffusion of stomach acid 
again so that gastric acidity can increase, back diffusion of gastric acid so that which causes damage to the tissue. gastric acidity does not increase and As an antioxidant, flavonoids can parietal cells can survive longer (Rostika, inhibit lipid peroxidation in the gastric 2012). The structure of parietal cells can mucosa so as to prevent an increase in cell be seen in Picture 2 . membrane permeability and do not occur
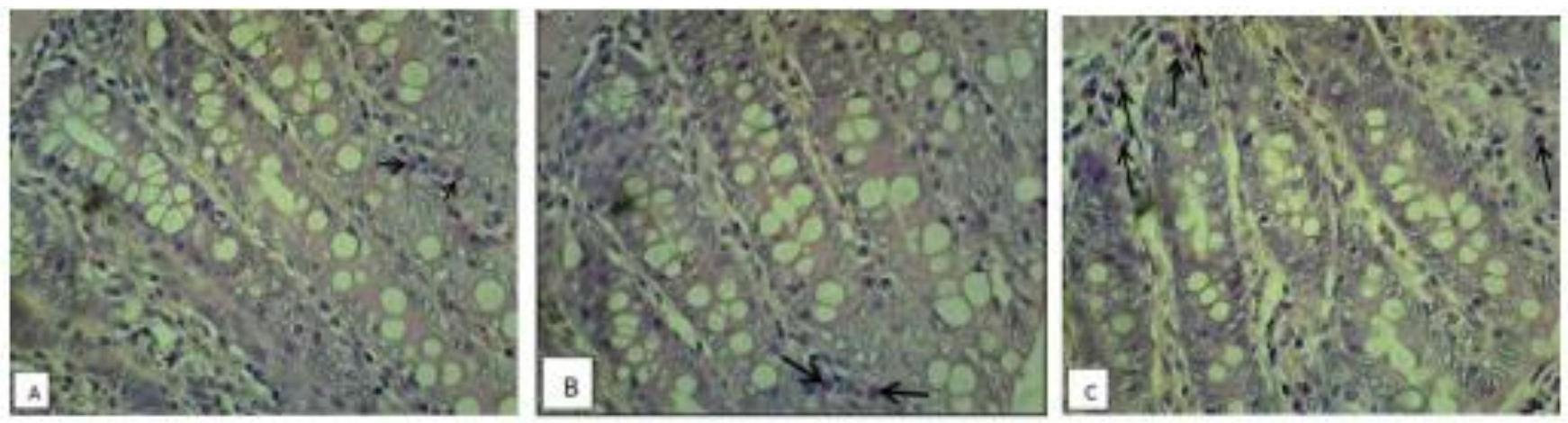

Picture 2. Parietal cells after treatment of avocado leaf extract (Persea americana)Black arrow ( ) indicates parietal cell

\section{CONCLUSION}

Based on the results of this study, it can be concluded that dose of $100 \mathrm{mg} / \mathrm{kg}$ bw show he optimum diuretic effect and has no effect on the histological structure of the stomach.

\section{REFERENCES}

Adha, A.C. (2009). Pengaruh Pemberian Ekstrak Etanol Daun Alpukat (Persea americana Mill.) Terhadap aktivitas Diuretik Tikus Putih Jantan Sprague-Dawley. Skripsi. Bogor: Fakultas Kedokteran Hewan Institut Pertanian Bogor.

Arukwe, U., Amadi, B.A., Duru, M.K.C., Agomuo,E.N., Adindu, E. A., Odika, P.C., Lele, K.C., Egejuru, L., \& Anudike, J. (2012). Chemical Composition of Persea americana Leaf, Fruit and Seed. IJRRAS .11(2):346-349

Bintari, G. S., Windarti, I., \& Fiana, D. N.(2014) Temulawak (Curcuma xanthorrhiza Roxb) Sebagai Pencegah Kerusakan Mukosa Lambung. Medical Journal of Lampung University. 3(5) :77-84
Dai J. \& Mumper R. (2010). Plant Fenolic : extraction, analysis, and their antioxidant and anticancer properties. Molecules.15(10): 7313-7352

Guyton, A. C., \& Hall, J. E., (2014). BukuAjar Fisiologi Kedokteran. Edisi ke-12. Jakarta:EGC Kedokteran.

Katja, D. G., Suryanto, E.,danWehantouw, F., ( Potensi daun alpukat (Persea americana Mill.) sebagai sumber antioksidan alami. Chemistry Progress. 2 (10):54-64

Kurniawan, R.F., (2014). Benefits of Avocado Avocado: Treat and Prevent All Diseases. Surabaya: Healthy Books

Mescher, A.L. (2017).Histologi Dasar Junquera Teks \& Atlas. Alih Bhs: Jan Tambayong. Edisi 14. Jakarta: Penerbit: EGC

Nessa, Arifin, H., dan Muchtar, H. (2013). Efek Diuretik Dan Daya Larut Batu Ginjal Dari Ekstrak Etanol Rambut Jagung (Zea mays L.). Prosiding Seminar Nasional Perkembangan Terkini Sains Farmasi dan Klinik III 2013: 345-358

Omodamiro, OD \& Jimoh, M.A. (2016). Assesment of In-vitro antioxidant and Diuretic potential of an ethanol seed extract of Persea americana in Wistar albino rats. The Pharmaceutical and Chemical Journal. 2016.3(4):134-143

Puspitasari, D. A.(2008). Gambaran Histopatologi Lambung Tikus Putih (Rattus norvegicus) Akibat Pemberian Asam Asetil Salisilat. 
Skripsi. Bogor: Fakultas Kedokteran Hewan Institut Pertanian Bogor.

Rahman, N., Dewi, N.U., \& Bohari. (2018). Phytochemical and Antioxidant Activity of Avocado Leaf Extract (Persea americana Mill.). Asian Journal of Scientific Research. 11 (3): 357-363,

Rostika, N. (2012). Pengaruh Pemberian Ekstrak Minyak Jintan Hitam (Nigella sativa) Terhadap Gambaran Histologi Organ Lambung Dan Usus Halus Mencit (Mus musculus). Skripsi. Bogor: Fakultas Kedokteran Hewan Institut Pertanian Bogor.

Sherwood. (2012). Fisiologi Manusia dari Sel ke Sistem. 6 Ed. Jakarta: Penerbit EGC.

Salawu, O.A., Tijani, A.Y., Obidike, I.C., Rafindadi, H.A., and Emeje, M. (2009). Anti - ulcerogenic properties of methanolic root extract of Piliostigma reticulatum (DC) Hoechst (Syn. Bauhinia reticulate DC) - Leguminosae in rats. African Journal of Pharmacy and Pharmacology. vol. 3(5), pp. 252-258.

Siswandono dan Soekardjo, B.(2008). Kimia Medisinal I. Surabaya: Airlangga University Press.

Wientarsih, I., R. Madyastuti., B. Febran., dan D. Firnanda.(2012). Gambaran Serum Ureum, dan Kreatinin Pada Tikus Putih Yang Diberi Fraksi Etil Asetat Daun Alpukat. Jurnal Veteriner. 13(1):57-62. 